\title{
FIRST RECORD OF Xanthopastis timais IN AMARYLLIS AND EFFECT OF SOURSOP EXTRACT ON LARVAL MORTALITY ${ }^{1}$
}

\author{
LÍGIA BROGLIO MICHELETTI², SÔNIA MARIA FORTI BROGLIO ${ }^{3 *}$, EURICO EDUARDO PINTO DE LEMOS ${ }^{3}$, \\ ROSEANE CRISTINA PREDES TRINDADE ${ }^{3}$, ELLEN CARINE NEVES VALENTE ${ }^{4}$
}

\begin{abstract}
The aim of this study was to report the occurrence of Xanthopastis timais (Cramer, 1780) (Lepidoptera: Noctuidae) in amaryllis (Hippeastrum hybridum Hort., Amaryllidaceae), as well as estimating lethal concentrations ( $\mathrm{LC}_{50}$ and $\mathrm{LC}_{99}$ ) of soursop seed extract, Annona muricata L. (Annonaceae), against its larvae. The experiment was carried out at the Laboratory of Entomology of the Research Center for Agricultural Sciences, Federal University of Alagoas, in Rio Largo-AL, Brazil. First, we collected caterpillars from amaryllis plants that were reared until pupal and adult stages (parental generation). Next, part of the adults was used for species identification, and the rest were bred to produce next generation (F1), being after that applied in a laboratory bioassay. The lab trial was performed in a completely randomized design, with six treatments and five replications containing three second-instar caterpillars. These larvae were fed pieces of amaryllis leaf $(4 \times 4 \mathrm{~cm})$, which were previously soaked in treatments for 30 seconds and, air-dried on absorbent papers for one hour. Each treatment consisted of one concentration of ethanol extract of soursop seeds $(0.0,1.0,0.5,0.25,0.125$ and $0.0625 \% \mathrm{w} / \mathrm{v})$ with distilled water and DMSO at $1 \%(\mathrm{v} / \mathrm{v})$, for solutions. We noted that the lethal concentrations $\mathrm{LC}_{50}$ and $\mathrm{LC}_{99}$ were $0.29 \%(\mathrm{w} / \mathrm{v})$ and $2.27 \%(\mathrm{w} / \mathrm{v})$, respectively. In view of our results, we can state that larval stage of $X$. timais were influenced by extract application in terms of survival, mortality, larvae weight and larval stage length. Besides of that, it was the first time this species was recorded in Alagoas state.
\end{abstract}

Keywords: Amaryllidaceae. Annona muricata. Floriculture. Spanish moth. Seeds.

\section{REGISTRO DE Xanthopastis timais EM AMARÍLIS E EFEITO DO EXTRATO DE GRAVIOLA NA MORTALIDADE LARVAL}

RESUMO - O objetivo deste trabalho foi relatar a ocorrência em Alagoas da espécie Xanthopastis timais (Cramer, 1780) (Lepidoptera: Noctuidae) em amarílis (Hippeastrum hybridum Hort., Amaryllidaceae) e avaliar o uso do extrato de sementes de graviola, Annona muricata L. (Annonaceae), estimando as concentrações letais $\left(\mathrm{CL}_{50}\right.$ e $\left.\mathrm{CL}_{99}\right)$ para as lagartas, bem como os efeitos na fase larval. O experimento foi conduzido no Laboratório de Entomologia do Centro de Ciências Agrárias da Universidade Federal de Alagoas em Rio Largo-AL. Foram coletadas lagartas em plantas de amarílis que foram criadas em folhas dessa planta, até a obtenção de pupas e de adultos (geração parental). Parte dos adultos foi usada para identificação específica, e outros, deram continuidade à geração seguinte (F1), que foi utilizada no bioensaio. O delineamento experimental foi inteiramente casualizado, constituído por seis tratamentos e cinco repetições com três lagartas de segundo ínstar por repetição. As lagartas foram alimentadas com porções de folhas de amarílis (4 x $4 \mathrm{~cm}$ ), anteriormente imersas em seus devidos tratamentos durante 30 segundos e secas ao ar sobre papel absorvente durante uma hora. Os tratamentos foram: extrato etanólico de sementes de graviola a 0,$0 ; 1,0 ; 0,5 ; 0,25 ; 0,125$ e $0,0625 \%$ $(\mathrm{p} / \mathrm{v})$, adicionado com água destilada e com o solvente DMSO a 1\% (v/v), para obtenção das soluções. As concentrações letais $\left(\mathrm{CL}_{50}\right.$ e $\left.\mathrm{CL}_{99}\right)$ foram $0,29 \%(\mathrm{p} / \mathrm{v})$ e $2,27 \%(\mathrm{p} / \mathrm{v})$, respectivamente. A fase larval foi afetada pelo uso do extrato em relação à sobrevivência, mortalidade, peso e duração do período. Registra-se pela primeira vez a ocorrência de $X$. timais em Alagoas.

Palavras-chave: Amaryllidaceae. Annona muricata. Floricultura. Mariposa Espanhola. Sementes.

\footnotetext{
*Corresponding author

${ }^{1}$ Received for publication in 04/12/2016; accepted in 08/17/2016.

${ }^{2}$ Department of Crop Production, Escola Superior de Agricultura “Luiz de Queiroz", Piracicaba, SP, Brazil; ligia_micheletti@hotmail.com. ${ }^{3}$ Center of Agricultural Sciences, Universidade Federal de Alagoas, Rio Largo, AL, Brazil; soniamfbroglio@gmail.com, eepl@uol.com.br, roseane.predes@uol.com.br.

${ }^{4}$ Instituto Federal de Educação, Ciência e Tecnologia de Alagoas, Maragogi, AL, Brazil; ellencvalente@yahoo.com.br.
} 


\section{INTRODUCTION}

Brazilian flower market is one of the most promising niches in contemporary agribusiness. In 2014, it was estimated that this sector generated around R\$ 5.6 billion for final consumer, which is equivalent to a gross production (GP) of $\mathrm{R} \$$ 1.6 billion (JUNQUEIRA; PEETZ, 2015).

Among the flower species grown in this country, amaryllis [Hippeastrum hybridum Hort. (Amaryllidaceae)] stands out for an annual production of 17 million bulbs, addressed mainly to the international market, aside from sales of 500 thousand vases to the domestic trade. The major growing states are São Paulo (Holambra city) and Ceará (Paraipaba city); the latter is fully focused on bulb production for exports (TOMBOLATO et al., 2010).

This plant is demanded and cultivated because of its exotic and attracting flowers. However, it rarely prospers in Brazilian environments due to severe and intense attacks of Xanthopastis timais (Lepidoptera: Noctuidae) (GIL-SANTANA; NIHEI; NUNEZ, 2014). Such insect has as main host plants belonging to the genera Amaryllidaceae, Iridaceae and

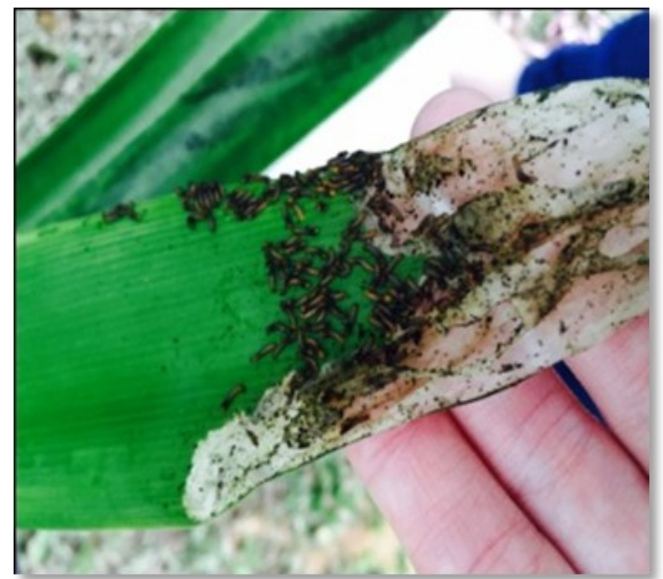

Liliaceae (TIETZ, 1972); moreover, it was also found in Lactuca sp. (Compositae) for laboratorial reared insects (COVELL JR., 1984). Females of $X$. timais are able to lay several hundreds of eggs grouped within sequences commonly found on abaxial leaf surface (ZANDT, FREEMAN, DAVENPORT, 2013). Larvae hatch within eight days, going through six stages in a larval period of 17 days; then, they pupate on soil, where remain for more 19 days. Last, adults live for eight to ten days, with each generation lasting for seven to eight weeks and producing up to six of them per year (BOURQUIN, 1935; HEPPNER, BARBARA, BUSS, 2009).

Injuries by $X$. timais caterpillars are significant in leaves, bulbs and roots of the host plants (Figure 1). Despite being very destructive, little information on such pest damages and its control are found in literature, though there are a few studies on new species of larval parasitoids (Diptera: Tachinidae) (TOMA, 2010; GIL-SANTANA, NIHEI, NUNEZ, 2014). Moreover, no insecticides are registered in Brazil for controlling pests in amaryllis (AGROFIT, 2016), nor knowledge about plant extracts to perform the control.

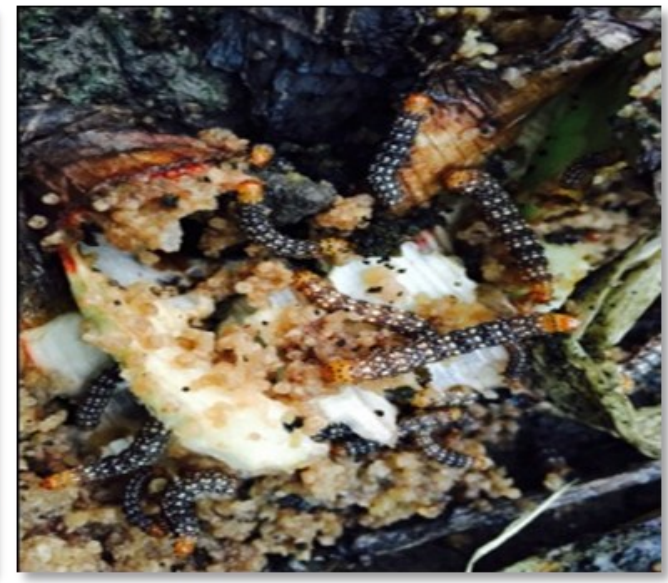

Figure 1. Caterpillars of Xanthopastis timais on leaves (A) and on bulbs (B) of amaryllis plants (Amaryllidaceae).

Accordingly, the search for plant extracts with insecticidal action becomes an interesting alternative for pest control. For instance, plants belonging to the Annonaceae group have been cited as an important group, since they have several secondary metabolites with biological activity in their composition, which, in turn, would decrease selection of resistant insect species (PINHEIRO et al., 2009; GOMES, 2013; LIMA et al., 2014). Within this botanical family, soursop (Annona muricata L.) should be highlighted for its scientifically proven insecticidal, nematicidal, acaricidal and bactericidal action; on top of that, its seeds, which are disposed during fruit processing, make a promising source of material to produce insecticidal extracts (HERNANDÉZ; $\quad$ ANGEL, 1997; BROGLIO-MICHELETTI et al., 2009; TRINDADE et al., 2011; KRINSKI; MASSAROLI; MACHADO, 2014; MACIEL et al., 2015).

Thus, the aim of this research was first to register the occurrence of $X$. timais in amaryllis grown in Alagoas state (Brazil), and then assessing the toxic effects of ethanol extracts from soursop seeds (A. muricata) on larval stage of this moth at $\mathrm{LC}_{50}$ and $\mathrm{LC}_{99}$ lethal concentrations.

\section{MATERIAL AND METHODS}

The current study was performed at the Laboratory of Entomology, which belongs to the Research Center for Agricultural Sciences, Federal University of Alagoas, in Rio Largo, AL, Brazil $\left(9^{\circ} 27^{\prime} 06^{\prime}\right.$ ' S and 35 49' 05', W), from September 
and November of 2014.

\section{Laboratory rearing of Xanthopastis timais}

Caterpillars were collected from amaryllis plants grown in home areas of the city of Maceió, Alagoas state, being individually placed into plastic pots $(200 \mathrm{~mL})$. After that, they were fed pieces of leaf $(4 \times 4 \mathrm{~cm})$ from potted plants, being daily replaced until the end of larval stage. Lending continuity to the biological cycle, they were left on a 3 -cm layer of sieved and sterile sand (forced-air oven for $48 \mathrm{~h}$ at $80^{\circ} \mathrm{C}$ ), as pupation substrate. Then, pupae were transferred to flat-bottom glass tubes $(2.5 \mathrm{~cm}$ diameter $\times 8.0 \mathrm{~cm}$ height) topped with cotton wool, separated according to sex, remaining for 24 hours after achieving pupal stage, as method described by Butt and Cantu (1962).

Once the adults have emerged, some of them were packaged and sent for identification to the Museum of Entomology of the São Paulo University (USP), in Piracicaba - SP (Brazil).

The remaining adults were caged $(20 \mathrm{~cm}$ diameter x $22 \mathrm{~cm}$ height) for mating and oviposition, leaving one male and one female per recipient. These cages were internally lined with waterproof paper, which served as substrate for laying, being supplied with water and honey solution (10\%) inside thereof, as source of carbohydrates for adults. In addition, these cages were topped with glass boards.

After harvested, eggs were put into Petri dishes on moistened paper filter, where stood until larvae hatching (F1). Newly, these larvae were individualized into plastic pots $(200 \mathrm{~mL})$ and fed pieces of amaryllis leaf ( 4 x $4 \mathrm{~cm}$ ), which were daily replaced up to second larval instar, when caterpillars were taken to perform the bioassay.

Effects of ethanol extract of Annona muricata seeds against Xanthopastis timais

\section{Extract preparation}

Soursop seeds were obtained in the city of Anadia-AL, from a fruit processing plant. They were packaged in Kraft paper bags and left to dry in an air-forced oven at $60{ }^{\circ} \mathrm{C}$ for 48 hours. After drying, they were ground (Wiley mill) for obtaining a fine powder, which was stocked in a hermetically sealed recipient, properly labelled, until extract preparation. An organic extract was prepared following the method proposed by Gomes (2013), in which the seed powder undergoes cold extraction with hexane $\left[\mathrm{CH}_{3}\left(\mathrm{CH}_{2}\right)_{4} \mathrm{CH}_{3}\right]$ (5L hexane for $2.3 \mathrm{~kg}$ powder) in a stainless steel percolator. The crude extract was filtered after 72 hours resting, being then submitted to solvent evaporation using a rotary evaporator at $50{ }^{\circ} \mathrm{C}$ under low pressure. The hexane extract was put into a pre-weighed glass vial, properly labeled and open-packaged for maximum evaporation of the solvent. After extraction, the resulting cake underwent ethanol extraction $\left(\mathrm{CH}_{3} \mathrm{CH}_{2} \mathrm{OH}\right)$, as method previously described, except for the solvent (4.6 $\mathrm{L}$ ethanol) and the number of replications, as there was only one cycle for hexane extract and three for the ethanol one (the same powder was used three continuous times).

At bioassay assembling, the crude extract which had been stored for two months in refrigerator was solubilized in water with dimethyl sulphoxide solvent (DMSO) at $1 \%(\mathrm{v} / \mathrm{v})$, and mixed for 15 minutes in magnetic stirrer. In doing so, each concentration was obtained from a stock solution primarily prepared ( $1 \%$ ethanol extract, $\mathrm{w} / \mathrm{v})$, being thus solubilized in distilled water and DMSO.

\section{Bioassay installation and conduction}

The bioassay was conducted under the following environmental conditions: $26 \pm 2{ }^{\circ} \mathrm{C}$, $75 \pm 10 \%$ UR and 12-h photoperiod. The experimental design was completely randomized with six treatments and five replications, and three caterpillar each. Water and DMSO at $1 \%(\mathrm{v} / \mathrm{v})$ made up control treatment. From stock solution, the other dilution series were $0.50 ; 0.25 ; 0.125$ and $0.0625 \%$ (w/ v). Afterwards, amaryllis leaf pieces of $4 \times 4 \mathrm{~cm}$ were soaked into each treatment for thirty seconds and air-dried on absorbent tissues for one hour. Thereupon, treated leaf pieces were distributed into individual Petri dishes $(6.4 \mathrm{~cm}$ diameter $\times 1.5 \mathrm{~cm}$ height), containing moistened filter paper on the bottom. Lastly, three second-instar caterpillars of $X$. timais were placed onto the amaryllis leaves.

After installation, these leaves were daily replaced by non-treated leaf pieces. Five days later, larvae from each plate were transferred to larger plastic pots $(200 \mathrm{~mL})$, keeping the same amount per container. Evaluations were daily carried out by taking notes of larvae mortality, survival and weight, at 12 days after soaking (DAS), as well as measuring the time each stage lasted. Finally, we estimated the lethal concentration $\mathrm{LC}_{50}$ and $\mathrm{LC}_{99}$ for each dose applied.

\section{Statistics}

For $\mathrm{LC}_{50}$ and $\mathrm{LC}_{99}$ calculations were made by Probit's analysis, through SAS software (SAS INSTITUTE, 2001).

Larval survival was analyzed by non-parametric chi-squared test of hypothesis. Survival data was based on mortality rates, and means were subjected to Log-Rank testing, by isolated pairs, using the Kaplan-Meyer's method, with the aid of Proc Lifetest (SAS INSTITUTE, 2001).

The variables mortality, larvae weight and larval period length underwent variance analysis 
(ANOVA), with means compared by the Tukey's test at $5 \%$ probability.

For all analyses, we used the statistical software from SAS Institute (2001).

\section{RESULTS AND DISCUSSION}

Upon species confirmation, it was stated the first record of Xanthopastis timais (CRAMER, 1780) (Lepidoptera: Hadeninae: Noctuidae) in Alagoas state. This insect species synonymy includes Xanthopastis amaryllidis Sepp., Xanthopastis heterocampa Guenée, Xanthopastis regnatrix Grote, Xanthopastis antillium Dyar, Xanthopastis moctezuma Dyar and Xanthopastis molinoi Dyar. It was firstly registered in Suriname, covering a geographical spread from North America (Alabama, Florida and Louisiana), passing through Caribe, South America, among other locations (HEPPNER, BARBARA, BUSS, 2009). In Brazil, this insect was observed for the first time in the states of Rio Grande do Sul, Santa Catarina, Pará and Rio de Janeiro (SPECHT; CORSEUIL, 2002; SPECHT; SILVA; LINK, 2004; ALMEIDA, SPECHT, TESTON, 2014; GIL-SANTANA; NIHEI; NUNEZ, 2014).

Lethal concentrations $\left(\mathrm{LC}_{50}\right.$ and $\left.\mathrm{LC}_{99}\right)$ on Xanthopastis timais caterpillars

The lethal concentrations ( $\mathrm{LC}_{50}$ and $\mathrm{LC}_{99}$ ) for $50 \%$ and $99 \%$ mortality in $X$. timais were estimated to be $0.29 \%(\mathrm{w} / \mathrm{v})$ and $2.27 \%(\mathrm{w} / \mathrm{v})$, respectively (Table 1). Similar values were found by Maciel et al. (2015), when studying A. muricata seed extract on mortality, repellency, egg viability and control of Tetranychus urticae (Acari: Tetranychidae). These authors claimed that $\mathrm{LC}_{50}$ was reached at $0.2 \%(\mathrm{v} / \mathrm{v})$ ethanol extract, presenting the highest toxicity. Differently, Gomes (2013) reported that doses of 0.013 and $0.084 \%$ of soursop extract achieved $\mathrm{LC}_{50}$ and $\mathrm{LC}_{99}$, respectively, against Plutella xylostella (Lepidoptera: Plutellidae).

Table 1. Lethal concentration $\left(\mathrm{LC}_{50}\right.$ and $\left.\mathrm{LC}_{99}\right)$ of ethanol extract of Annona muricata seeds against Xanthopastis timais larvae.

\begin{tabular}{|c|c|c|c|c|c|c|c|}
\hline Treatments & $\mathrm{n}^{1}$ & $\mathrm{DF}^{2}$ & $\begin{array}{c}\text { Slope } \\
\pm \text { SEM }^{3}\end{array}$ & $\mathrm{LC}_{50}(\%)\left(\mathrm{CI}^{4} 95 \%\right)$ & $\mathrm{LC}_{99}(\%)(\mathrm{CI} 95 \%)$ & $\chi^{2,5}$ & $P$ \\
\hline Ethanol extract & 75 & 3 & $\begin{array}{r}1.4076 \\
\pm 0.3390\end{array}$ & $\begin{array}{c}0.28562 \\
(0.20785-0.40631)\end{array}$ & $\begin{array}{c}2.26580 \\
(1.1869-8.66357)\end{array}$ & 6.1862 & 0.1029 \\
\hline
\end{tabular}

${ }^{1}$ Number of caterpillars; ${ }^{2} \mathrm{Chi}$-square degree of freedom; ${ }^{3}$ Standard error of the mean; ${ }^{4}$ Confidence interval; ${ }^{5} \mathrm{Chi}$-square.

\section{Survival, mortality, weight and larval period length for Xanthopastis timais}

Survival rates were lower for $X$. timais larvae fed leaves treated with the highest doses of ethanol extract. The non-parametric hypothesis testing $\left(\chi^{2}=\right.$ $\left.68.43^{<0.0001}\right)$ highlighted difference among treatments. By analyzing mean comparisons, we noticed that insect survival varied from 1 to 18 days for $1 \%$ treatment and control, respectively, being statistically different. In general, the other treatments differed from these ones but not among themselves (Table 2).

Table 2. Biological variables (Mean \pm EP) of Xanthopastis timais larvae fed amaryllis leaves treated with ethanol extract of soursop seeds at various concentrations.

\begin{tabular}{ccccr}
\hline Treatments & $\begin{array}{c}\text { Survival } \\
\text { (days) }\end{array}$ & $\begin{array}{c}\text { Mortality } \\
(\%)\end{array}$ & $\begin{array}{c}\text { Weight } \\
(\mathrm{g})\end{array}$ & $\begin{array}{c}\text { Larval period } \\
\text { length (days) }\end{array}$ \\
\hline $1 \%$ & $1.00 \pm 0.00 \mathrm{a}$ & $100.00 \pm 0.00 \mathrm{a}$ & -1 & $1.00 \pm 0.00 \mathrm{a}$ \\
$0.5 \%$ & $5.67 \pm 1.63 \mathrm{~b}$ & $100.00 \pm 0.00 \mathrm{a}$ & $0.32 \pm 0.13 \mathrm{~b}$ & $5.20 \pm 1.59 \mathrm{a}$ \\
$0.25 \%$ & $14.17 \pm 1.93 \mathrm{bc}$ & $100.00 \pm 0.00 \mathrm{a}$ & $0.53 \pm 0.09 \mathrm{~b}$ & $17.47 \pm 2.68 \mathrm{~b}$ \\
$0.125 \%$ & $13.20 \pm 1.93 \mathrm{~b}$ & $66.66 \pm 14.91 \mathrm{a}$ & $1.01 \pm 0.03 \mathrm{a}$ & $16.67 \pm 1.58 \mathrm{~b}$ \\
$0.0625 \%$ & $10.50 \pm 0.96 \mathrm{~b}$ & $26.66 \pm 12.47 \mathrm{~b}$ & $1.32 \pm 0.15 \mathrm{a}$ & $16.73 \pm 0.87 \mathrm{~b}$ \\
Testemunha & $18.33 \pm 0.67 \mathrm{c}$ & $5.56 \pm 13.61 \mathrm{~b}$ & $1.39 \pm 0.07 \mathrm{a}$ & $18.07 \pm 0.07 \mathrm{~b}$ \\
\hline $\mathrm{CV}(\%)$ & - & 24.69 & 22.28 & 26.28 \\
\hline$\chi^{2}$ & $68.43^{2}$ & - & - & - \\
\hline
\end{tabular}

Means followed by the same letter in the column do not differ from each other, by the Tukey's test, at 5\% probability for mortality, weight and larval stage length.

${ }^{1}$ Statistical analysis was not performed because all caterpillars died.

${ }^{2}<0.0001$.

The caterpillars fed leaves treated with concentrations of 1.0 and $0.5 \%$ were able to survive less than the other treatments ( 1 and 5 days, respectively). Similarly, Carvalho et al. (2008) evaluated plant extracts to control Oligonychus ilicis (Acari: Tetranychidae) under laboratory conditions; they observed through survival rates that the extract of Annona squamosa L. at $0.72 \%, 1.12$ and $1.52 \%$ 
promoted levels of female mortality above $50 \%$ on the fourth, third and fourth days, respectively; at these concentrations survival probability was of $48.3 \%$.

Likewise, in the current study, larval mortality was influence by the concentrations of soursop extract. Total mortality was reached by treatments 1.0, 0.50 and $0.25 \%$, however not differing from the dose of $0.125 \%$, which achieved a rate of $66.66 \%$. Control and $0.0625 \%$ dose had no difference between each other, but differed from the other treatments, showing mortality rates of $5.56 \%$ and $26.66 \%$, respectively. The caterpillars which died became dark and downsized, which is consistent with the results of Trindade et al. (2011), who assessed $A$. muricata extract on P. xylostella at 1, 2, 3,4 and $5 \mathrm{mg} \cdot \mathrm{mL}^{-1}$; these authors reported an increasing mortality of larvae from the lowest to the highest concentration, reaching $100 \%$ at 12 days after treatment.

Brito (2014) studied bioactivity of ethanol extracts of $A$. muricata seeds and leaves against Tuta absoluta Meyrick, 1917 (Lepidoptera: Gelechiidae), on tomato plants. They ascertained that these extracts were efficient to control larvae at a concentration of $1,000 \mathrm{ppm}(0.10 \%)$. This result was similar to our study, in which concentrations near $0.10 \%(0.125 \%)$ killed $66.66 \% X$. timais. Interestingly, Blessing et al. (2010), assessing the extract of Annona montana Macfad. (araticum) on Spodoptera frugiperda (Lepidoptera: Noctuidae), reported 100\% mortality of larval and pupal stages, using a concentration $(0.01 \%)$ quite lower than the one found here.

Oppositely, Rodrigues et al. (2014) verified that hexane extract of $A$. muricata seeds was more effective than the one extracted from leaves, even using the same concentration $(0.50 \%)$, in controlling Aphis craccivora Koch, 1854 (Hemiptera: Aphididae) on cowpea Vigna unguiculata (L) Walp. (Fabaceae), leading to average mortality rates of $98.9 \%$ and $11.1 \%$, respectively.

The insecticidal activity of Annonaceae is due to acetogenins, which act on mitochondria inhibiting $\mathrm{NADH}$ - ubiquinone oxidoreductase, causing insect death. These substances are natural products, promising as insecticide prototype, being commonly found in branch and root barks, roots and seeds of plants belonging to the Annonaceae family (BERMEJO et al., 2005; CASTILLO-SÁNCHEZ; JIMÉNEZ-OSORNIO; DELGADO-HERRERA, 2010).

Other studies have already been carried to assess the effects of Annona extracts on larvae of several insect species, using different concentrations. One of them was performed by Silva, Pereira and Bento (2007); these authors tested extract from Annona coriacea Mart. on tomato leafminers, $T$. absoluta, at 0.50, 1.0, 2.0, 4.0 and 8.0\%, and noted that the lowest concentration caused mortality of $86.4 \%$, while the others reached $100 \%$. In our study, the concentration of $0.50 \%$ enabled a control of $100 \%$ caterpillars. As mentioned above, Blessing et al. (2010) found a mortality of $100 \%$ for $S$. frugiperda, using a quite low concentration $(0.01 \%)$ of $A$. montana Macfad. extract. In the same line, Massaroli (2013) compared crude extracts of seeds from two species (Annona mucosa Jacq. and Annona crassiflora Mart.) at $0.50,1.0,2.0,4.0$ and $8.0 \%$ against first-, third- and fifth-instar larvae of Chrysodeixis (=Pseudoplusia) includens (Walker) (Lepidoptera: Noctuidae), via ingestion. They found that $A$. mucosa had high efficiency to control all larval instars, showing to be toxic by acting on growth hormones.

Besides that, recent studies have been assessing Annona extract effects against mites. In view of that, Carvalho et al. (2008) tested 79 plant extracts (leaves) of several species and indicated Annona squamosa L. as the most toxic to Oligonychus ilicis (Acari: Tetranychidae), leading to a higher mortality at a dose of $11200 \mathrm{ppm}(1.12 \%)$. Given our results, we may speculate that acetogenins in soursop leaves were lethal to the insect concerned, even in concentrations similar to those using seed extract. When testing an organic seed extract of $A$. muricata on Tetranychus evansi (BAKER; PRITCHARD, 1960) (Acari: Tetranychidae), Lima et al. (2014) inquired about its acaricidal effect, both against protonymph and female adults, after 24 hours application, reaching better results at superior concentrations (5.0\%); however, at doses far different from those tested here $(1.0 \%$ and $0.5 \%)$.

Average weight of caterpillars fed leaves treated with $1.0 \%$ could not be measured at 12 DAS, since all larvae had died from day one. Surviving caterpillars from 0.50 and $0.25 \%$ treatments had a reduced weight, differing from the other treatments. Brito (2014), when testing A. muricata extract on $T$. absoluta larvae, mentioned an approximate result with significant differences between the weights of treated insects and those of control. This author attributed such weight reduction to decreasing feed intake, once eating inhibitors might be present or even because of harmful effects caused by $A$. muricata extracts to the intestinal cells, restricting food digestion and absorption.

On top of that, extract concentrations of 1.0 and $0.5 \%$ influenced larval stage duration. Caterpillars ingesting leaves treated with $1 \%$ died on the very first day after treatment, and those treated with $0.5 \%$ died on the fifth day. Conversely, Brito (2014) observed a prolongation of life stages for $T$. absoluta, using a concentration of $1,000 \mathrm{ppm}$ $(0.10 \%)$, increasing exposition to natural enemies, as well as the average time of each generation, reducing thus population growth.

For this reason, we may infer that detecting and monitoring $X$. timais become utmost actions that should be performed daily. Once infestation is found, extracts must be immediately applied, since the pest 
is voracious feeder and can destroy the entire plant in a short time. Therefore, it is necessary to use a concentration that causes an acute effect, because the remaining caterpillars may keep feeding on plants, destroying them fast.

\section{CONCLUSIONS}

This was the first record of Xanthopastis timais damaging amaryllis plants in the state of Alagoas.

The lethal concentrations of ethanol extract from soursop seeds $\left(\mathrm{LC}_{50}\right.$ and $\mathrm{LC}_{99}$ ) able to cause $50 \%$ and $99 \% X$. timais mortality were $0.29 \%(\mathrm{w} / \mathrm{v})$ and $2.27 \%(\mathrm{w} / \mathrm{v})$, respectively.

Larval stage is indeed affected by ethanol extract of soursop seeds.

The concentrations of 1.0 and $0.5 \%(\mathrm{w} / \mathrm{v})$ promoted an acute larval mortality for $X$. timais.

\section{ACKNOWLEDGEMENTS}

To National Council for Scientific and Technological Development - CNPq by Research Productivity Scholarship granted to the second author, and to researcher Dr. Sinval Silveira Neto, for identifying the species (Xanthopastis timais).

\section{REFERENCES}

AGROFIT. Sistema de Agrotóxicos Fitossanitários. Disponível em: <http:// agrofit.agricultura.gov.br/agrofit_cons/ principal_agrofit_cons>. Acesso em: 21 fev. 2016.

ALMEIDA, L. P.; SPECHT, A. B.; TESTON, J. A. Fauna of Noctuidae (Lepidoptera: Noctuoidea) in a pasture area in Altamira, Eastern Amazon, Pará, Brazil. Brazilian Journal of Biology, São Carlos, v. 74, n. 4, p. 983-990, 2014.

BERMEJO, A. et al. Acetogenins from Annonaceae: recent progress in isolation, synthesis and mechanisms of action. Natural Product Reports, London, v. 22, n. 2, p. 269-303, 2005.

BLESSING, L. T. et al. Antifeedant and toxic effects of acetogenins from Annona montana on Spodoptera frugiperda. Journal of Pest Science, New York, v. 83, n. 3, p. 307-310, 2010.

BOURQUIN, F. Metamorfosis de Xanthopastis timais Cr. (Lep. Noct.). Revista de la Sociedad Entomológica Argentina, Buenos Aires, v. 7, n. 1, p. 195-201, 1935.
BRITO, E. F. Bioatividade de extratos de anonáceas e piperáceas sobre Tuta absoluta (Meyrick) (Lepidoptera: Gelechiidae) em tomateiro. 2014. 92 f. Tese (Doutorado em Agronomia: Área de Concentração em Proteção de Plantas) - Universidade Estadual Paulista, Botucatu, 2014.

BROGLIO-MICHELETTI, S. M. F. et al. Extratos de plantas no controle de Rhipicephalus (Boophilus) microplus (Canestrini, 1887) (Acari: Ixodidae) em laboratório. Revista Brasileira de Parasitologia Veterinária, Jaboticabal, v. 18, n. 4, p. 44-48, 2009.

BUTT, B. A.; CANTU, E. Sex determination of Lepidopterous pupae. Washington: USDA, 1962. 7 p. (USDA. ARS-33-75).

CARVALHO, T. M. B. et al. Avaliação de extratos vegetais no controle de Oligonychus ilicis (McGregor, 1917) (Acari: Tetranychidae) em laboratório. Coffee Science, Lavras, v. 3, n. 2, p. 94-103, 2008.

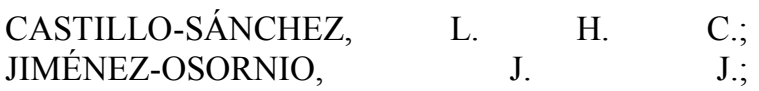
DELGADO-HERRERA, M. A. Secondary metabolites of the Annonaceae, Solanaceae and Meliaceae families used as biological control of insects. Tropical and Subtropical Agroecosystems, Yucatán, v. 12, n. 3, p. 445-462, 2010.

COVELL JR., C. V. Field Guide to the Moths of Eastern North America. Boston: Houghton-Mifflin, 1984. $496 \mathrm{p}$

GIL-SANTANA, H. R.; NIHEI, S. S.; NUNEZ, E Lespesia melloi sp. nov. (Diptera: Tachinidae) from Brazil, a parasitoid of Xanthopastis timais (Lepidoptera: Noctuidae). Journal of Insect Science, Annapolis, v. 14, n. 121, p. 1-9, 2014.

GOMES, I. B. Toxicidade e formulação de extratos de Annona muricata L. (Annonaceae) para o controle de Plutella xylostella (L., 1758) (Lepidoptera: Plutellidae). 2013. 88 f. Dissertação (Mestrado em Proteção de Plantas: Área de Concentração em Entomologia) - Universidade Federal de Alagoas, Rio Largo, 2013.

HEPPNER, J. B.; BARBARA, K. A.; BUSS, E. A. 2009. Spanish Moth or Convict Caterpillar, Xanthopastis timais (Cramer) (Insecta: Lepidoptera: Noctuidae). University of Florida. Disponível em: <http://entnemdept.ufl.edu/creatures/ orn/flowers/spanish moth.htm>. Acesso em: 15 set. 2015 .

HERNANDÉZ, C. R.; ANGEL, D. N. Anonaceas con propiedades insecticidas. In: SÃO JOSÉ, A. R. 
et al. (Eds.). Anonáceas: produção e mercado (pinha, graviola, atemóia e cherimólia). Vitória da Conquista: Universidade Estadual do Sudoeste da Bahia, 1997. p. 229-239.

JUNQUEIRA, A. H.; PEETZ, M. S. As campanhas de marketing na floricultura brasileira. Jornal Entreposto, Hortica Consultoria Disponível em: $<$ http://www.jornalentreposto.com.br/noticias/74agromarketing/618-as-campanhas-de-marketing-nafloricultura-brasileira>. Acesso em: 08 nov. 2015.

KRINSKI, D.; MASSAROLI, A.; MACHADO, M. Potencial inseticida de plantas da família Annonaceae. Revista Brasileira de Fruticultura, Jaboticabal, v. 36, n. 1, p. 225-242, 2014.

LIMA, H. M. A. et al. Toxicidade do extrato orgânico de sementes de Annona muricata L. (Annonaceae) sobre Tetranychus evansi (Baker \& Pritchard, 1960) (Acari: Tetranychidae) em tomateiro. Revista Brasileira de Biociências, Porto Alegre, v. 12, n. 4, p. 201-205, 2014.

MACIEL, A. da G. S. et al. Effect of Annona muricata L. (1753) (Annonaceae) seeds extracts on Tetranychus urticae (Koch, 1836) (Acari: Tetranychidae). African Journal of Agricultural Research, Ago-Iwoye, v. 10, n. 48, p. 4370-4375, 2015.

MASSAROLI, A. Efeito de extratos de annonáceas sobre a lagarta falsa medideira Chrysodeixis includens (Walker 1857) (Lepidoptera: Noctuidae). 2013. 52 f. Dissertação (Mestrado em Ciências: Área de Concentração em Zoologia) - Universidade Federal do Paraná, Curitiba, 2013.

PINHEIRO, M. L. B. et al. Acanthoic acid and other constituents from the stem of Annona amazonica (Annonaceae). Journal of the Brazilian Chemical Society, Campinas, v. 20, n. 6, p. 1095-1102, 2009.

RODRIGUES, V. M. et al. Avaliação de extratos de Annona muricata L. sobre Aphis craccivora Koch, 1854 (Hemiptera: Aphididae). Revista Brasileira de Agroecologia, Pelotas, v. 9, n. 3, p. 75-83, 2014.

SAS Institute INC. 2001. Statistical analysis system. Release 8.2. (Software). Cary. USA.

SILVA, A. P. T.; PEREIRA, M. J. B.; BENTO, L. F. Extrato etanólico da semente de aracitum (Annona coriacea) (Mart.) sobre a mortalidade da traça-do-tomateiro (Tuta absoluta). Revista Brasileira de Agroecologia, Pelotas, v. 2, n. 2, p. 1150-1153, 2007. noctuídeos (Lepidoptera, Noctuidae) em Salvador do Sul, Rio Grande do Sul, Brasil. Revista Brasileira de Zoologia, Curitiba, v. 19, n. 1, p. 281-298, 2002.

SPECHT, A.; SILVA, E. J. E.; LINK, D. Noctuídeos (Lepidoptera, Noctuidae) do Museu Entomológico Ceslau Biezanko, Departamento de Fitossanidade, Faculdade de Agronomia "Eliseu Maciel", Universidade Federal de Pelotas, RS. Revista Brasileira de Agrociência, Pelotas, v. 10, n. 4, p. 389-409, 2004.

TIETZ, H. M. An index to the described life histories, early stages and hosts of the Macrolepidoptera of the Continental United States and Canada. Sarasota: Allyn Museum of Entomology, 1972. 104 p.

TOMA, R. Contribuição ao conhecimento de espécies venezuelanas de Lespesia Robineau-Desvoidy (Diptera, Tachinidae, Exoristinae), com descrições de novas espécies. Revista Brasileira de Entomologia, Curitiba, v. 54, n. 2, p. 165-172, 2010.

TOMBOLATO, A. F. C. et al. Bulbosas ornamentais no Brasil. Revista Brasileira de Horticultura Ornamental, Campinas, v. 16, n. 2, p. 127-138, 2010 .

TRINDADE, R. C. P. et al. Larvicidal activity and seasonal variation of Annona muricata (Annonaceae) extract on Plutella xylostella (Lepidoptera: Plutellidae). Revista Colombiana de Entomología, Bogotá, v. 37, n. 2, p. 223-227, 2011.

ZANDT, P. A. VAN; FREEMAN, P. L.; DAVENPORT, L. J. Sporadic destructive occurrence of Convict Caterpillars (Xanthopastis timais) on Cahaba lilies (Hymenocallis coronaria). Southern Lepidopterists' News, Safety Harbor, v. 35, n. 1, p. 5-14, 2013.

SPECHT, A.; CORSEUIL, E. Diversidade dos 